\title{
Adaptability - how to accommodate changing user preferences
}

\begin{abstract}
Purpose When current accommodation is unsatisfactorily, office organisations consider relocating to new accommodation that optimally facilitate their main processes, supporting image and financial yield. However, due to high vacancy levels, public opinion and governmental awareness oppose new office construction. Reusing existing buildings could be the egg of Columbus. This paper aims at answering the questions: Which property characteristics are important push and pull factors for relocation? What does this mean for the decision: stay or go?
\end{abstract}

Design/methodology/approach Besides a literature review of factors determining organisations' accommodation choices, interviews were held with large-scale office organisations and creative organisations, discussing relocation drivers. Henceforth, a survey was held among creative organisations, collecting data about property characteristics important for their preferences.

Findings Traditional push factors like car accessibility, extension need, and poor location and building image remain important. Sustainability issues like reducing energy consumption and better public transportation accessibility are highly prioritised pull factors. Regarding the creative industries, bikeand public transportation accessibility, multi-tenancy, and ICT and meeting facilities are most important.

Practical implications Knowing office users' preferences is important to attract and retain stable tenants. If office space supply is highly aligned to end-users demands and easily adaptable to changing needs, probably more organisations will decide to stay instead of go, leaving behind empty offices.

Originality value This study combines data about push and pull factors with relocation decisionmaking, innovatively focussing on the creative industries. The data can be used to explore opportunities and risks of adaptive re-use of the existing building stock.

Keywords: offices, vacancy, user preferences, creative industries

\section{Introduction}

New ways of working and the financial and real estate crises reduce the need for office space. Simultaneously, overproduction characterised office market developments after 2000 . As a consequence office markets have become replacement markets without a quantitative need for new office buildings: new buildings drive out bad buildings. In the Netherlands, currently $15 \%$ of the office space is vacant, of which $60 \%$ is structurally vacant, meaning vacancy for three or more years.

When relocating, office organisations consider buildings and locations within geographically defined markets that optimally facilitate their main processes and support image and financial yield. Sustainable and durable office space is important for image, status and possible expansion. Hitherto, new office developments were the response to this demand. Meanwhile, public opinion and governmental awareness oppose new office construction in markets with high vacancy. New ideas are needed to realise durable office space while limiting new developments. For this reason a sound understanding of user needs and preferences is of outmost importance. Knowledge about prioritized user needs can be helpful to design and manage a durable building stock and to explore the opportunities and risks of redesign and upgrade of the existing building. This paper aims at answering the questions: Which property characteristics are important push and pull-factors for office organisations considering relocation? What does this mean for the decision: should I stay or should I go?

This study focuses on office user accommodation preferences in connection to location and building characteristics. Because of the growing creative industry sector, particular attention is being paid to 
the preferences of office organisations working in this sector. This paper is based on empirical studies of the Dutch office market and office user preferences.

\section{Office user needs and prioritised aspects}

The current office market condition, where the office user has extensive accommodation options, has highlighted the significance of office property quality (DTZ 2011). An office building may become obsolete and remain vacant, because its features do not meet current users' requirements. When still occupied, current or prospective users derive less utility from the office building and are not willing to pay high rent. In both cases the rent revenues for the investor decrease. Regarding rent levels, Rodenburg (2005) considered the valuation of multifunctional land use by different groups of actors. Real estate investors were asked to rate location characteristics by their effect on the rent price per square metre office space. The characteristics were ranked according to importance as follows: accessibility by car, image of the area, geographical location, accessibility by public transport, proximity to Schiphol airport, quality of real estate, labour market, business cluster, multifunctionality, high-visible location, presence of clients, and presence of suppliers. Employees at the South Axis in Amsterdam were then asked to give their view on multi-functionality using a Willingness to Pay study (Rodenburg 2006). The study showed that employees were willing to contribute financially to multi-functional design of their working environment.

\section{Push and pull factors in case of relocation}

Accommodation decision-making of office organisations is complex and based on preferences for location, building, facilities and price factors that are intertwined and influence each other. In literature, four types of factors are mentioned that affect location and accommodation choices: push, pull, keep- and reject factors (Meester and Pellenbarg 1986). Push factors describe the situation when the current building or location no longer meets the needs of the user. Pull factors indicate a high attractiveness of alternative options. Keep factors are reasons to stay in the current building, and reject factors describe reasons that discourage an organisation to settle in a building. The vast majority of migration studies are limited to the push and pull factors. If the keep factors are stronger than the pull or push factors, it is likely that no relocation occurs.

Several Dutch market-surveys revealed the main push factors in the selection of office accommodation. Office tenants are asked to rate a number of location and building characteristic according to their perceived importance from 1 (not important) to 10 (very important). Lack of space, accessibility and representativeness of the location and the building are weighty motives for moving and as such important push-factors (see Table 1). 
Table 1: Push factors based on different studies

\begin{tabular}{|l|l|l|l|l|}
\hline $\mathbf{1 9 7 7}$ & $\mathbf{1 9 8 8}$ & $\mathbf{1 9 9 9}$ & $\mathbf{2 0 0 8}$ & $\mathbf{2 0 1 2}$ \\
\hline $\begin{array}{l}\text { Lack of expansion } \\
\text { space }\end{array}$ & $\begin{array}{l}\text { Lack of expansion } \\
\text { space }\end{array}$ & $\begin{array}{l}\text { Lack of expansion } \\
\text { space }\end{array}$ & $\begin{array}{l}\text { Lack of expansion } \\
\text { space }\end{array}$ & $\begin{array}{l}\text { Organizational } \\
\text { considerations }\end{array}$ \\
\hline $\begin{array}{l}\text { Organizational } \\
\text { considerations }\end{array}$ & $\begin{array}{l}\text { Organizational } \\
\text { considerations }\end{array}$ & $\begin{array}{l}\text { Organizational } \\
\text { considerations }\end{array}$ & $\begin{array}{l}\text { Organizational } \\
\text { considerations }\end{array}$ & $\begin{array}{l}\text { Environmental } \\
\text { reasons }\end{array}$ \\
\hline $\begin{array}{l}\text { Poor conditions of } \\
\text { the premises }\end{array}$ & $\begin{array}{l}\text { Local traffic } \\
\text { situation }\end{array}$ & $\begin{array}{l}\text { Optimistic } \\
\text { expectations for } \\
\text { the future }\end{array}$ & $\begin{array}{l}\text { Optimistic } \\
\text { expectations for } \\
\text { the future }\end{array}$ & $\begin{array}{l}\text { Poor conditions of } \\
\text { the premises }\end{array}$ \\
\hline $\begin{array}{l}\text { Threat of } \\
\text { expropriation/lease } \\
\text { termination }\end{array}$ & $\begin{array}{l}\text { Poor conditions of } \\
\text { the premises }\end{array}$ & $\begin{array}{l}\text { No representative } \\
\text { building }\end{array}$ & $\begin{array}{l}\text { No representative } \\
\text { building }\end{array}$ & $\begin{array}{l}\text { Lack of expansion } \\
\text { space }\end{array}$ \\
\hline $\begin{array}{l}\text { No representative } \\
\text { environment }\end{array}$ & $\begin{array}{l}\text { No representative } \\
\text { building }\end{array}$ & $\begin{array}{l}\text { Poor conditions of } \\
\text { the premises }\end{array}$ & $\begin{array}{l}\text { Poor conditions of } \\
\text { the premises }\end{array}$ & $\begin{array}{l}\text { Poor accessibility } \\
\text { by public } \\
\text { transport }\end{array}$ \\
\hline
\end{tabular}

Sources: Pellenbarg (1976), Besselink et al. (1988), Kok (1999), Boelens (2008) and Hendrikx (2012).

Comparability of the latter study with the former studies is limited due to a different way of selecting respondents

Based on the literature, (Remøy et al. 2007) developed a list of 15 building characteristics and 6 location characteristics considered to be important pull-factors for office organisations relocating in the Dutch office market. Using a Delphi survey method, accommodation experts were interviewed and asked to rank the location and building characteristics that influence office organisations choice when relocating. The experts were asked to focus on office organisations in Amsterdam, with the largest target groups being medium and large scale financial and business services companies. Error! Not a valid bookmark self-reference. shows the average ranking of prioritised aspects. Accessibility by cars and public transport, car parking, an attractive appearance of the location and flexibility of the building showed to be highly prioritized aspects in case of relocation. Here, too, environmental issues like comfort, energy performance and space efficiency score high on the list of preferred characteristics.

Table 2 Prioritised property characteristics in relocation decisions

\begin{tabular}{l|l}
\hline Building characteristics & Location characteristics \\
\hline 1. Car parking & 1. Accessibility by car \\
\hline 2. Exterior appearance & 2. Status \\
\hline 3. Layout flexibility & 3. Accessibility by public transport \\
\hline 4. Space efficiency & 4. Facilities \\
\hline 5. Comfort & 5. Safety \\
\hline 6. Interior appearance & 6. Business cluster \\
\hline 7. Recognisable user & \\
\hline 8. Technical state & \\
\hline 9. Building facilities & \\
\hline 10. Year of construction & \\
\hline 11. Security & \\
\hline 12. Energy performance & \\
\hline 13. Routing & \\
\hline 14. Bike parking & \\
\hline 15. Commodities logistic & \\
\hline
\end{tabular}

Vacancy as an indicator of a mismatch between supply and demand

Studies of the Amsterdam office market revealed the location and building characteristics of office properties with a high level of vacancy (Remøy, 2010). Though location characteristics describing the location as mono-functional (tested by the functional mix and availability of facilities) were found to be highly influential, building characteristics were found to be the most important predictors for structural vacancy. Office buildings with low flexibility (described by the size of standard floors, measurements 
of the main structural grid and the facade grid) were found to have higher odds of structural vacancy. Equally, office buildings with a poor external appearance, defined by a technically outdated and poorly maintained facade were found to have increased risk of structural vacancy. On the other hand, a spatially comfortable entrance as a measure for the interior appearance of the building was found to decrease the odds of structural vacancy. Measured as the free height of the entrance in relationship to its floor space, the variable describes the spatial proportions of the entrance. Entrances with relatively low ceilings and large surfaces are experienced as low and unpleasant, whereas entrances with relatively high ceilings and small surfaces are experienced as narrow and unfriendly. Apparently, office users prefer a well-balanced ratio between ceiling height and floor space.

In conclusion, office buildings that have an increased risk of structural vacancy can be described by the following location and building characteristics:

- year of construction between 1980 and 1995

- location with insufficient facilities

- low status locations

- monofunctional locations

- less parking places than surrounding buildings

- functional obsolescence

- glass facades

- low quality interior

- technical decay

\section{Additional data-collection and methods}

To unravel the influence of property characteristics further, two additional studies have been conducted using different types of interviews, a survey and site visits, all based on the stated preferences of office organisations and accommodation experts. The first study focused on large scale office organisations, the second one on the creative industries. Third, a comparison has been made between user preferences and building and location characteristics of vacant buildings.

\section{a. Interviews with large scale office organisations}

Twenty interviews were held with large scale office organisations (Hendrikx 2012). The interviews included structured interview questions and were partly conducted as open interviews. The structured part was set up to test current user preferences towards the preferences that were found in former studies (Pellenbarg 1976; Besselink et al. 1988; Kok et al. 1999; Boelens 2008). The open part was carried out to find out whether organisations now consider relocation motives that were not mentioned in former studies, and whether other aspects have become important for accommodation preferences.

\section{b. Data-collection on user preferences of the creative industries}

While in the production economy large organisations were needed to achieve competitive advantage, in the modern knowledge society increasingly often we see small organisations which operate together to integrate knowledge from different disciplines. This is the principle of a network organisation. Flexibility, meeting and knowledge transfer are key elements to achieve results. Currently the creative industries show the most resemblance to the principles of a network (Florida 2003; Florida 2004; Florida 2010). The creative industry is the engine for a successful knowledge economy. Currently, the creative industries are often accommodated in old industrial buildings, equipped with facilities to encourage companies to work together. According to organisation experts, in the future more companies will operate within a network of companies. The creative industry is ahead of other sectors and exposes trends that are picked up by more conventional companies. For this reason, the accommodation preferences of the creative industry were examined on three levels: location, building and supporting facilities (Arkenbout 2012). The latter category is rarely mentioned in real estate research, but seems important for this user group. 
According to the Standard Industrial Classification - SIC - from 2009, the creative industries can be divided into three sub-sectors: creative business services, arts, and media \& entertainment. For each sub-sector user preferences were determined by a literature review, a Delphi study, and a survey among 800 respondents. In addition three creative clusters in the Netherlands (Caballero factory, HAKA building and Kauwgomballenfabriek) were visited to explore its main characteristics and themes to be included in the survey questionnaire.

In the Delphi study 28 experts were asked to rank user preferences of the creative industries in order of importance, for each of the three different sub-sectors. The Delphi study consisted of two rounds of questions and a feedback session. In the first round the panellists were asked to spend 5-10 minutes to rank the characteristics according to importance. The results per panellist were collected. Subsequently, the data were analysed on degree of similarity in prioritization on the basis of the statistical coefficient Kendall W. The second round took place by e-mail. Here the panellists were informed about their own results compared to the results of the other panel members and asked whether they would alter their former judgement. Based on round two a final list was drawn from ten location characteristics, eleven building characteristics and eleven types of supporting facilities arranged in order of importance. Based on these results the three highest scoring aspects per scalelevel were selected. These nine aspects were resubmitted to the experts, asking them to rank these aspects in order of importance.

The insights from the Delphi study were used to set out a survey among 800 respondents spread over 19 creative clusters in the Netherlands. In this survey the users were asked about the importance of housing characteristics at the level of location, building and use, as recognised from the Delphi study. Additional questions were asked about the importance of external appearance, meeting places, recognition of the user, cooperation and whether or not sharing facilities. The response rate was nearly 25 percent, of which three quarters had completed the questionnaire. This seems sufficient to be able to draw conclusions.

\section{c. Comparison between user preferences and characteristics of structurally vacant buildings}

Based on the assumption that vacancy is an indicator of a mismatch with user demands, the user preferences of the creative class and the large scale organisations were compared to the building characteristics of structurally vacant office buildings as determined in former research (Remøy 2010). This could add to a better understanding of both reasons for vacancy and opportunities for adaptive re-use, provided that vacant buildings are sufficiently adaptable to facilitate office users' preferences. Henceforth, the characteristics of vacant buildings were checked against the characteristics of buildings that are well adaptable considering within use adaptations but also conversions into housing, as defined by Wilkinson and Remøy (2011).

Previous research grouped characteristics of adaptability potential under economic, social, environmental, technological, legal and physical categories (Remøy and Van der Voordt 2007). Key factors were found to be the local economy, along with attributes like site, age, physical condition, heritage value and size (Fianchini 2007). Building quality and character were determinants of successful adaptation, together with accessibility, layout and flexibility for a range of differing uses (Ball 2002; Fianchini 2007).

Technical issues found to influence office adaptations are building size and height, depth, structure, envelope and cladding type, floor layout and access, services, acoustic separation and fire safety (Gann and Barlow 1996).

Finally, the location of a building is important for adaptation, with older buildings occupying prime locations (Ball 2002). Within the paradigm of sustainability, accessibility by car and public transportation adds to the feasibility of adaptation (Ellison and Sayce 2007). Remøy and Van der Voordt (2007) found that adaptations hardly take place in mono-functional locations, as these locations are less desired. 


\section{Research findings}

\section{a. User preferences of large scale office organisations}

Like in the literature review, expansion, accessibility (especially by public transport), and representativeness are important motives for relocations. The increased importance of environmental factors and new ways of working, together with an increasing need for social interaction are remarkable. Once, 'culture' due to the fusion of different cultures after a merger, or an ending lease period, is mentioned. Similar arguments were used to describe pull factors, supplemented by 'central location in the Netherlands' and 'Low land prices'. The main Keep factors mentioned were a positive image of the place, 'emotional bond' and tradition (the company is traditionally established here). Main objections for moving were the high investment and relocation costs, human considerations (longer travel or necessity to move for employees), owning the property and fear for less productivity during the relocation period. It is remarkable that eleven of the thirteen surveyed users made a serious consideration between staying and moving. Decisive motives in this assessment are often the characteristics of the current location, results of the business case, annual accommodation costs for different scenarios and sustainability. Other motives, such as cooperation with the current owner and emotional connection also play a role. Also, the choice between moving to a new or an existing building is usually seriously considered. The choice for new construction is often motivated by the mismatch between the demand and supply of existing construction, limited adaptability of existing buildings and financial considerations. The arguments to opt for existing buildings vary from a fast moving process, flexibility and short leases, to a need for identity and sustainability.

Table 3 shows the push-factors mentioned by the interviewees i.e. the number of respondents that mentioned a particular issue as a consideration to move to a new building or an existing one or to stay (last column), and the weighted score i.e. the number of respondents multiplied by $0=$ not important at all, $1=$ of little importance, $2=$ important, $3=$ very important, and $4=$ mentioned spontaneously (Hendrikx 2012).

There is a growing focus on sustainability, whereby users' interest for adaptation increase. There is also a growing demand for flexible and short leases, active asset management and shared services and facilities. A number of investors are already responding to this question. Additionally, asset managers mention keeping good contact with the tenant as an important ingredient in property management, together with careful technical management of the property, preserved quality, the possibility to break open and renew contracts (e.g. in return for less $\mathrm{m} 2$ ) and the use of incentives. 
Table 3: Considerations to stay or go

\begin{tabular}{|l|r|r|r|r|r|}
\hline & $\begin{array}{l}\text { People that } \\
\text { moved to a } \\
\text { new } \\
\text { building }\end{array}$ & $\begin{array}{l}\text { People that } \\
\text { moved to an } \\
\text { existing } \\
\text { building }\end{array}$ & $\begin{array}{l}\text { People that } \\
\text { stayed } \\
\text { (Renovation) }\end{array}$ & $\begin{array}{l}\text { Total } \\
\text { Score }\end{array}$ & $\begin{array}{l}\text { Number of } \\
\text { respondents } \\
\text { mentioning } \\
\text { this aspect }\end{array}$ \\
\hline Organizational considerations & 2 & 11 & 4 & 17 & 6 \\
\hline Sustainability & 0 & 6 & 6 & 12 & 4 \\
\hline Poor state of the building & 4 & 4 & 2 & 10 & 4 \\
\hline No opportunities for extension & 0 & 10 & 0 & 10 & 3 \\
\hline Poor accessibility by public transport & 4 & 4 & 0 & 8 & 2 \\
\hline Building not representative & 5 & 2 & 1 & 8 & 4 \\
\hline Location not representative & 4 & 4 & 0 & 8 & 2 \\
\hline No nice living conditions & 2 & 3 & 2 & 7 & 4 \\
\hline No flexible rent opportunities & 0 & 3 & 2 & 5 & 3 \\
\hline Optimistic future expectations & 0 & 3 & 2 & 5 & 3 \\
\hline Lack of parking facilities & 1 & 1 & 2 & 4 & 3 \\
\hline Inadequate traffic circumstances & 0 & 1 & 2 & 3 & 2 \\
\hline Poor contact with local authorities & 0 & 2 & 0 & 2 & 1 \\
\hline Changing production & 0 & 0 & 2 & 2 & 1 \\
\hline Inadequate work climate & 0 & 2 & 0 & 2 & 1 \\
\hline Poor accessibility in general & 0 & 2 & 0 & 2 & 1 \\
\hline Absence of knowledge centres & 0 & 1 & 0 & 1 & 1 \\
\hline Annoyance in/from environment & 0 & 0 & 1 & 1 & 1 \\
\hline Poor location regarding customers & 1 & 0 & 0 & 1 & 1 \\
\hline Other (miscellaneous) & 8 & 6 & 0 & 14 & 4 \\
\hline & & & & & \\
\hline & 0 & & & & \\
\hline
\end{tabular}

\section{b. User preferences of creative industries}

Which accommodation characteristics are most important in terms of location, building and facilities varies by sub-sector. The creative business service sector has different requirements than the arts and media \& entertainment sector. Regarding location and facilities needs the preferences of the three sub-sectors are almost identical, but on building level, clear differences were found. Artists attach particular importance to a flexible layout and commercial space with additional free floor height. The creative business services and media \& entertainment attach more value to the representativeness of the accommodation, recognition and appearance of the image of the organisation.

\section{User preferences regarding the location}

For the creative industries accessibility, social security and the presence of a restaurant or café are important when choosing a business location. The presence of other facilities in the surrounding is less important. The creative industry prefers business premises well accessible by bicycle and close to public transport. To ensure customer satisfaction it is desirable if the business premises are also easily accessible by car. Furthermore, the social security of the location is of great importance. A secure location with less risk of burglaries represents a pleasant living environment. Usually, areas with different functions and facilities are regarded safe, as twenty-four hour activity is created. The presence of for example a bar and restaurant is a means to achieve a twenty-four hour active area. Furthermore, cafes in the area work as a third workplace where people can meet, work and share knowledge. According to the respondents of the survey a restaurant and café are not important for choosing a business location. This is in contrast to the results from literature and expert interviews. This may have to do with a different frame of reference of practice experts and users.

\section{User preferences regarding the building}

The creative industry prefers flexible buildings, the layout should fit multiple tenants and should offer different separate business units, and the interior should be representative. The user wants layout flexibility and the ability to rent more or less square metres. The creative industry prefers accommodation in a building where common areas are shared with co-tenants, as a means and 
opportunity for new cooperation, knowledge transfer and cost sharing. Offering several small premises in the same building is desirable for this target group. With regard to the recognition and visibility of the business premises, the creative industry generally attaches more value to a representative interior than exterior. They want an inspiring creative working environment where innovation is stimulated.

\section{User preferences regarding supporting facilities}

The creative industry ascribes value to facilities and services included in the rent, such as internet (wifi), security and meeting places. Offering business support and flexibility are important for the choice of business premises for young business organisations in the creative industries. Facilities that are more related to functional aspects are less important when choosing a business location and score lower in importance. Table 4 gives an overview of the survey findings (Arkenbout 2012).

Table 4: Preferred accommodation characteristics by three sub-sectors of the creative industries

\begin{tabular}{|c|c|c|}
\hline A. Creative Business Service & B. Art & C. Media \& Entertainment \\
\hline \multicolumn{3}{|l|}{ Location } \\
\hline $\begin{array}{l}\text { Accessibility by public } \\
\text { transportation }\end{array}$ & Accessibility by bike & Accessibility by bike \\
\hline Accessibility by car & $\begin{array}{l}\text { Accessibility by public } \\
\text { transportation }\end{array}$ & Accessibility by car \\
\hline Restaurant and café & Restaurant and café & Restaurant and café \\
\hline Parking & Security & Security \\
\hline Security & Accessibility by car & $\begin{array}{l}\text { Accessibility by public } \\
\text { transportation }\end{array}$ \\
\hline Accessibility by bike & Other businesses & Parking \\
\hline Other businesses & Parking & Other businesses \\
\hline Quality of public space & Quality of public space & Quality of public space \\
\hline Stores & Stores & Stores \\
\hline Cultural facilities & Cultural facilities & Cultural facilities \\
\hline Housing present & Housing present & Housing present \\
\hline \multicolumn{3}{|l|}{ Building } \\
\hline Multi-tenant building & Comfort & Multi-tenant building \\
\hline Comfort & Multi-tenant building & Comfort \\
\hline Interior finish & Layout flexibility & Interior finish \\
\hline Small business units & Story height & Recognisability \\
\hline Layout flexibility & Small business units & Small business units \\
\hline Recognisability & Recognisability & Layout flexibility \\
\hline Exterior appearance & Interior finish & Exterior appearance \\
\hline Story height & Exterior appearance & Story height \\
\hline Building shape & Building shape & Building shape \\
\hline Energy use & Energy use & Energy use \\
\hline Technical state & Technical state & Technical state \\
\hline \multicolumn{3}{|l|}{ Facilities } \\
\hline Internet (wifi) & Security & Internet (wifi) \\
\hline Meeting places & Meeting places & Security \\
\hline Security & Internet (wifi) & Meeting places \\
\hline Monthly rent-contract & Monthly rent-contract & Monthly rent-contract \\
\hline Restaurant and café & Restaurant and café & Restaurant and café \\
\hline Reception & Reception & Reception \\
\hline Repro facilities & Repro facilities & Repro facilities \\
\hline Cleaning service & Cleaning service & Cleaning service \\
\hline Waste management & Waste management & Waste management \\
\hline Catering vending & Catering vending & Catering vending \\
\hline Textile care & Textile care & Textile care \\
\hline
\end{tabular}


Some clear differences were found between the preferences of large scale companies and the small scale creative industries (see tables 3 and 4). It is not clear however, whether or not the creative industries are fore-runners predicting changing user preferences of large scale offices, or whether creative industries change preferences once they grow and become more established firms.

\section{c. Comparison between characteristics of structurally vacant buildings and user preferences}

When comparing building and location characteristics of vacant properties to user preferences, a mismatch is found between the characteristics that describe preferred properties and the characteristics that describe structurally vacant office properties (Table 5). The comparison shows that several of the user preferences are not met by structurally vacant office buildings. A representative location is specifically important for large-scale office organisations, while facilities in the location are important for creative organisations. Comparing the building characteristics, functional obsolescence is a characteristic of structurally vacant office buildings, while it is measured by several factors that are important for the user preferences. Likewise, glass, facade, low quality interior and technical decay are also measured by several user preferences factors that are important for large-scale and creative organisations accommodation preferences.

Table 5: Comparison between characteristics of structurally vacant buildings and user preferences

\begin{tabular}{|c|c|}
\hline Characteristics vacant properties & User preferences \\
\hline year of construction between 1980 and 1995 & $\begin{array}{l}\text { Year of construction is a proxy for other factors, } \\
\text { and not measured as user preference }\end{array}$ \\
\hline location with insufficient facilities & $\begin{array}{l}\text { Restaurants and cafés no } 3 \text { location characteristic } \\
\text { for creative organisations }\end{array}$ \\
\hline low status locations & $\begin{array}{l}\text { Representative location no } 3 \text { characteristic for } \\
\text { large-scale organisations }\end{array}$ \\
\hline monofunctional locations & $\begin{array}{l}\text { Multifunctional location no } 7 \text { and } 8 \text { characteristic } \\
\text { for large-scale organisations, no } 3 \text { and } 7 \text { location } \\
\text { characteristic for creative organisations }\end{array}$ \\
\hline less parking places than surrounding buildings & $\begin{array}{l}\text { Parking no } 5 \text { location characteristic for creative } \\
\text { organisations, no } 11 \text { characteristic for large-scale } \\
\text { organisations }\end{array}$ \\
\hline functional obsolescence & $\begin{array}{l}\text { Represented by no } 2,3 \text { and } 5 \text { building } \\
\text { characteristic for creative organisations, no } 3 \text { and } \\
6 \text { for large-scale organisations }\end{array}$ \\
\hline glass facades & Represented by no 6 for large-scale organisations \\
\hline low quality interior & $\begin{array}{l}\text { Represented by no } 2 \text { and } 3 \text { building characteristic } \\
\text { for creative organisations, no } 2,3 \text { and } 15 \text { for } \\
\text { large-scale organisations }\end{array}$ \\
\hline technical decay & $\begin{array}{l}\text { Represented by no } 3,7,9 \text { and } 10 \text { building } \\
\text { characteristic for creative organisations, no 2, 3, } \\
4 \text { and } 6 \text { for large-scale organisations }\end{array}$ \\
\hline
\end{tabular}

\section{Conclusion and discussion}

The literature review and the additional Delphi study, expert interviews and survey clearly showed that traditional factors like accessibility by car, a need for extension, and poor location and building image remain important push factors. Environmental issues like reducing energy consumption, better accessibility by public transportation, and other sustainability issues are highly prioritised pull factors. Regarding the creative industries, accessibility by public transportation and by bike, multi-tenancy, and ICT and meeting facilities are most important. These needs cannot always be accommodated in existing buildings. A mismatch with user preferences leads to obsolescence and redundancy of specific office locations and buildings. However, new office developments are not necessarily the answer to changing user demands. Small scale creative industry organisations prefer adapted buildings to new buildings. The assumed price of accommodation in new offices is one of the drivers for this 
preference, but more important is the expectation of the possibilities generated by an existing built environment.

The relocation arguments of large scale organisations show that sustainability is increasingly playing a role in decision making. At a first glance new construction appears better suited technically and financially to meet sustainability demands than renovation of existing buildings. However, the demand for sustainable offices is much greater than can be achieved by the low annual addition to new. Reuse or adaptation of existing buildings ensures big savings on building materials waste and transport when compared to demolition and new construction.

Large buildings with sufficient services, possible to subdivide into separately lettable units, with sufficient parking and a facade that can be adapted to a modern external appearance are most likely to be adapted or converted. Only few vacant offices in central urban locations have characteristics that make adaptation difficult to realise. Buildings on an office/distribution location however, are less easily adapted, because of their location characteristics. However, the adaptation of large scale buildings like Caballerofabriek, Kauwgomballenfabriek etc. for the creative industries have shown that also this kind of adaptation is possible. The large size and possibility of attracting a substantial number of companies and users seem to be critical success factors.

\section{References}

Arkenbout, R. (2012). Kantoor binnenste buiten - Gebruikersvoorkeuren bedrijfshuisvesting creatieve industrie in Nederland. MSc Research, Delft University of Technology.

Ball, R. M. (2002). "Re use potential and vacant industrial premises: revising the generation issue in Stoke on Trent." Journal of Property Research 19: 93-110.

Besselink, H., M. van Greene, et al. (1988). "Veranderende vestigingstendensen." Groningen: Geografisch Instituut Rijksuniversiteit Groningen.

Boelens, M. (2008). "Motieven voor bedrijfsmigratie. Een onderzoek naar de verhuismotieven van bedrijven in Nederland." Order 501: 903.

DTZ (2011). The Netherlands, a national picture. The Netherlands, a national picture. v.o.f., D. Z. Amsterdam, DTZ Zadelhoff v.o.f. 2011: 80.

Ellison, L. and S. Sayce (2007). "Assessing sustainability in the existing commercial property stock." Property Management 25(3): 287-304.

Fianchini, M. (2007). "Fitness for purpose. A performance evaluation methodology for the management of university buildings." Facilities 25(3/4): 137-146.

Fianchini, M. (2007). "Fitness for purpose. A performance evaluation methodology for the management of university buildings." Facilities 25(3/4): 137-146.

Florida, R. (2003). "Cities and the Creative Class." City \& Community 2(1): 3-19.

Florida, R. (2004). The rise of the creative class ... and how it's transforming work, leisure, community and everyday life. New York, Basic Books.

Florida, R. (2010). The great reset: how new ways of living and working drive post-crash prosperity, HarperCollins.

Gann, D. and J. Barlow (1996). "Flexibility in building use: the technical feasibility of converting redundant officces into flats." Construction Management \& Economics 14(1): 55-66.

Hendrikx, T. (2012). Blijven of verhuizen? Minder leegstand door binding van de huurder. MSc Research, Delft University of Technology.

Kok, J., G. Menkhorst, et al. (1999). "Migratieprocessen anno 1999." Groningen: Faculteit der Ruimtelijke Wetenschappen Rijksuniversiteit Groningen.

Meester, W. J. and P. H. Pellenbarg (1986). Subjectieve waardering van bedrijfsvestigingsmilieus in Nederland, Geografisch Instituut Rijksuniversiteit Groningen.

Pellenbarg, P. (1976). "Bedrijfsmigratie in Nederland: een onderzoek naar migratiemotieven en hun betekenis voor regionale ontwikkeling." Deel I: terreinverkenning, Geografisch Instituut, Rijksuniveriteit Groningen.

Remøy, H., P. W. Koppels, et al. (2007). Characteristics of vacant offices: A Delphi-approach. In: Boelhouwer, P., D. Groetelaers, A. Ouwehand and E. Vogels, ENHR Rotterdam 2007, Rotterdam.

Remøy, H. and D. J. M. Van der Voordt (2007). Conversion of office buildings; a cross-case analysis. In, BSA 2007, Tokyo. Tokyo Metropolitan University. 
Remøy, H. (2010). Out of office, a study of the cause of office vacancy and transformation as a means to cope and prevent. Amsterdam, IOS.

Rodenburg, C. A. (2005). Measuring Benefits of Multifunctional Land Use; Stated Preferences Studies on the Amsterdam Zuidas, Vrije Universiteit Amsterdam.

Rodenburg, C. A. (2006). "Quantification of economic benefits of multifunctional land use-An empirical analysis among employees." Journal of Housing and the Built Environment 21(1): 69-81.

Wilkinson, S. J. and H. Remøy (2011). Sustainability and within use office building adaptations: $A$ comparison of Dutch and Australian practices. In: Anderson, K., Pacific Rim Real Estate Society, Gold Coast. Bond University. 